\title{
Standing sedation with medetomidine and butorphanol in captive African elephants (Loxodonta africana)
}

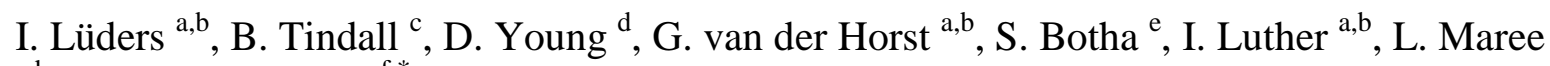
a,b H. J. Bertschinger f,*

${ }^{a}$ Department of Medical Biosciences, University of the Western Cape, Private Bag X17, Bellville 7535, South Africa

${ }^{b}$ National Zoological Gardens of South Africa, 323 Boom Street, Pretoria 0110, South Africa

${ }^{c}$ Robberg Veterinary Clinic, 56 Longships, Plettenberg Bay 6600, South Africa

${ }^{d}$ African Elephant Research Unit, Plettenberg Bay, South Africa

${ }^{e}$ African Lion Safari, 1386 Cooper Road, Cambridge, ON, N1R 5S, Canada

${ }^{f}$ Section of Reproduction, Faculty of Veterinary Science, University of Pretoria, Private Bag X04, Onderstepoort 0110, South Africa

* Corresponding author. Tel.: +27 128043312

E-mail address: henkbert@tiscali.co.za (H.J. Bertschinger).

\begin{abstract}
Doses for standing sedation allowing for various procedures in otherwise inaccessible, untrained captive African elephant bulls are presented. Thirty-three standing sedations were performed in 12 males aged 8 to 30 years (1-4 sedations per animal). Each bull received a combination of $0.009 \pm 0.002 \mathrm{mg} / \mathrm{kg}$ medetomidine and $0.03 \pm 0.007 \mathrm{mg} / \mathrm{kg}$ butorphanol. Full sedation was reached on average 25.5 min after injection. The addition of hyaluronidase (1000-2000 IU) significantly reduced time to full sedation to $16.5 \mathrm{~min}$ (paired $t$ test, $P=$ 0.024). Reversal was induced with intramuscular atipamezole $0.008( \pm 0.002)$ and naltrexone $0.035( \pm 0.015) \mathrm{mg} / \mathrm{kg}$. Recovery took on average $7 \mathrm{~min}(3-18 \mathrm{~min})$. The medetomidine/butorphanol combination provided safe standing sedation for smaller procedures.
\end{abstract}

Keywords: Elephant bull; Butorphanol; Medetomidine; Hyaluronidase 
When training or adequate handling facilities (such as a restraint chute) are lacking, chemical restraint becomes an option for accessing and handling elephants more safely for selected procedures. Many drugs are in use for chemical restraint in elephants (Table 1) but standing sedation is considered to pose a lower risk to captive elephants compared to general anaesthesia. It also allows access to both sides of the animal and, in general, elephant care staff find it more acceptable (Neiffer et al., 2005). The $\alpha_{2}$-adrenoceptor agonists, such as xylazine and detomidine, in combination with either ketamine or butorphanol have been used for standing sedation in African elephants (Table 1) but the use of medetomidine, a more potent and safe $\alpha_{2}$-agonist, has so far only been reported for Asian elephants (Sarma et al., 2002).

The aim of this study was to define doses of medetomidine and butorphanol combinations to achieve safe and effective standing sedation in captive African elephant bulls of different ages in order to perform procedures like semen collection and transrectal ultrasound examinations.

Twelve captive bulls, 8-30 years old, from four facilities in South Africa were used in the study (Table 2). Shoulder height was measured during each sedation and mean weight was calculated from this value using four different, previously published formulas (Johnson and Buss, 1965; Hanks, 1972; Laws et al., 1975). The bulls were sedated once (n=4), or three to four times $(n=8)$ over a period of 3 years. All procedures were carried out in accordance with the Animal Use and Care Committee of the University of Pretoria (permit V016-12; 24 April 2012). 


\section{Table 1}

Overview of previously published sedative, anaesthetic and reversal drugs used in adult African and Asian elephants. Doses are given in $\mathrm{mg} / \mathrm{kg}$ unless otherwise stated. Drug effects may differ based on age, sex, body condition and health status of the elephant. Modified from Fowler and Mikota (2006).

\begin{tabular}{|c|c|c|c|c|c|}
\hline \multirow{2}{*}{$\begin{array}{l}\text { Drugs used for } \\
\text { chemical } \\
\text { restraint }\end{array}$} & \multirow[t]{2}{*}{ Purpose, action } & \multicolumn{2}{|c|}{ Dose (mg/kg) for: } & \multirow[b]{2}{*}{ Route } & \multirow[t]{2}{*}{ Comments } \\
\hline & & Sedation & $\begin{array}{c}\text { Full } \\
\text { immobilisation }\end{array}$ & & \\
\hline Ketamine & Non-narcotic sedative & $\begin{array}{l}\text { Not used alone in } \\
\text { elephants }\end{array}$ & & IM & $\begin{array}{l}\text { Only in combination with } \\
\text { tranquilizer or } \alpha_{2} \text {-agonist }\end{array}$ \\
\hline Xylazine & Sedative, $\alpha_{2}$-agonist & $0.08-0.1$ & $0.15-0.2$ & IM & $\begin{array}{l}\text { Best in combination with } \\
\text { ketamine or butorphanol }\end{array}$ \\
\hline Detomidine & Sedative, $\alpha_{2}$-agonist & 0.0055 & & IM & Asian elephant only \\
\hline Medetomidine & Sedative, $\alpha_{2}$-agonist & 0.04-0.08 & & IM & \\
\hline Butorphanol & Immobilizer, opiate & $0.01-0.03$ & & IM & \\
\hline Etorphine & Immobilizer, opiate & & $0.0015-0.003$ & IM & $\begin{array}{l}\text { Usually in combination } \\
\text { with azaperone or } \alpha_{2^{-}} \\
\text {agonist }\end{array}$ \\
\hline Azaperone & $\begin{array}{l}\text { Short-acting } \\
\text { tranquilizer }\end{array}$ & $0.056-0.107$ & & IM,IV & \\
\hline $\begin{array}{l}\text { Azaperone/ } \\
\text { butorphanol }\end{array}$ & Standing sedation & $\begin{array}{l}\text { Azaperone: } 0.12 \\
\text { Butorphanol: } 10 \mathrm{mg} \\
\text { total dose }\end{array}$ & & IM & Single report \\
\hline $\begin{array}{l}\text { Xylazine/ } \\
\text { butorphanol }\end{array}$ & Standing sedation & $\begin{array}{c}0.035-0.16 \\
0.005-0.036\end{array}$ & & $\begin{array}{l}\text { IM or } \\
\text { IV }\end{array}$ & $\begin{array}{l}\text { Use lower dose for IV } \\
\text { administration }\end{array}$ \\
\hline $\begin{array}{l}\text { Xylazine/ } \\
\text { ketamine }\end{array}$ & $\begin{array}{l}\text { Standing sedation } \\
\text { or full immobilization }\end{array}$ & $\begin{array}{l}0.1 \pm 0.04 \\
0.6 \pm 0.13\end{array}$ & $\begin{array}{c}0.2 \\
1.0-1.5\end{array}$ & IM & \\
\hline $\begin{array}{l}\text { Detomidine/ } \\
\text { butorphanol }^{\text {a }}\end{array}$ & Standing sedation & $\begin{array}{l}0.013-0.02 \\
0.013-0.02\end{array}$ & & IM & $\begin{array}{l}1: 1 \text { ratio }(50-70 \mathrm{mg} \text { total } \\
\text { dose for each drug })\end{array}$ \\
\hline Diprenorphine & $\begin{array}{l}\text { Opioid receptor } \\
\text { antagonist }\end{array}$ & $0.0083 \pm 0.001$ & & & \\
\hline Naltrexone & $\begin{array}{l}\text { Opioid receptor } \\
\text { antagonist }\end{array}$ & $1 \mathrm{mg} / 1 \mathrm{mg}$ narcotic & & $\mathrm{IM}$ & \\
\hline Naloxone & $\begin{array}{l}\text { Opioid receptor } \\
\text { antagonist }\end{array}$ & 0.004 & & IM & or $10-50 \mathrm{mg}$ total dose \\
\hline Atipamezole & $\begin{array}{c}\alpha_{2} \text {-adrenerdgic } \\
\text { antagonist }\end{array}$ & $1 \mathrm{mg} / 10 \mathrm{mg}$ xylazine & & $\begin{array}{l}\text { IM or } \\
\text { slow IV }\end{array}$ & \\
\hline Yohimbine & Xylazine antagonist & $0.05-0.13$ & & IV & \\
\hline
\end{tabular}

IM, intramuscular; IV, intravenous

${ }^{a}$ Neiffer et al. (2005) 


\section{Table 2}

Total anaesthetic and reversal drug doses per elephant for 33 standing sedations performed in 12 male African elephants once or 3-4 times over a 3-year period.

\begin{tabular}{|c|c|c|c|c|c|c|c|c|c|c|c|}
\hline \multicolumn{4}{|c|}{ Elephant bull } & \multicolumn{2}{|c|}{ Sedation } & \multicolumn{2}{|c|}{ Top-up } & \multirow[b]{2}{*}{$\begin{array}{l}\text { Reversal } \\
\text { Time to } \\
\text { reversal }(\mathbf{m i n})^{\mathrm{b}}\end{array}$} & \multirow[b]{2}{*}{$\begin{array}{l}\text { Atipamezole } \\
(\mathrm{mg})\end{array}$} & \multirow[b]{2}{*}{$\begin{array}{l}\text { Naltrexone } \\
\quad(\mathrm{mg})\end{array}$} & \multirow[b]{2}{*}{ Route } \\
\hline Number & $\begin{array}{c}\text { Age } \\
\text { (years) }\end{array}$ & $\begin{array}{l}\text { Calculated } \\
\text { weight } \\
\text { (kg) }\end{array}$ & $n=$ & $\begin{array}{l}\text { Medetomidine } \\
(\mathrm{mg})\end{array}$ & $\begin{array}{l}\text { Butorphanol } \\
\text { (mg) }\end{array}$ & $\begin{array}{l}\text { Medetomidine } \\
\text { /butorphanol } \\
\text { (mg) }\end{array}$ & $\begin{array}{l}\text { Time }(\min )^{\mathrm{a}} \\
\quad \text { route }\end{array}$ & & & & \\
\hline 1 & 19 & 2662 & 1 & 20 & 85 & & & 55 & 20 & 100 & IM \\
\hline 2 & 8 & 1657 & 1 & 20 & 50 & & & $90^{\mathrm{c}}$ & 25 & $50 / 100$ & IV, IM \\
\hline 3 & $10-13$ & $1994-2316$ & 3 & $14-20$ & $40-60$ & $8 / 25$ & 25/IM & 74 & $15-25$ & $80-150$ & $\mathrm{IM}$ \\
\hline 4 & $23-26$ & $4230-5029$ & 4 & $21-50$ & $100-150$ & $8-10 / 25$ & 30/IV & 74 & $25-40$ & $100-250$ & IV, IM \\
\hline 5 & $23-26$ & $4147-4935$ & 4 & $20-50$ & $100-200$ & $10 / 25$ & $2 / \mathrm{IV}$ & 83 & $30-40$ & $100-250$ & IV, IM \\
\hline 6 & $23-26$ & $4443-4843$ & 4 & $50-55$ & $100-135$ & $10-15 / 25$ & $25-30 / \mathrm{IV}$ & 108 & $20-40$ & $100-150$ & IV, IM \\
\hline 7 & $25-28$ & $4172-4336$ & 4 & $35-50$ & $100-145$ & $10 / 20$ & $25 / \mathrm{IV}$ & 61 & $30-35$ & $100-150$ & IM \\
\hline 8 & $24-27$ & $3595-4025$ & 4 & $25-40$ & $75-100$ & & & 63 & $25-35$ & $100-150$ & $\mathrm{IM}$ \\
\hline 9 & $17-21$ & $2401-3197$ & 3 & $15-30$ & $70-100$ & $5 / 10$ & $25 / \mathrm{IV}$ & 69 & $20-25$ & $80-100$ & IV, IM \\
\hline 10 & $12-15$ & $2124-3232$ & 3 & $10-30$ & $40-100$ & & & 64 & $10-25$ & $60-100$ & $\mathrm{IM}$ \\
\hline 11 & 20 & 3033 & 1 & 40 & 75 & $10 / 25$ & 26/IV & 86 & 20 & 100 & $\mathrm{IV}, \mathrm{IM}$ \\
\hline \multirow[t]{2}{*}{12} & 30 & 5815 & 1 & 50 & 150 & & & 58 & 25 & 150 & $\mathrm{IV}, \mathrm{IM}$ \\
\hline & & Mean dose & $\begin{array}{l}\mathrm{g} / \mathrm{kg} \\
\mathrm{SD}\end{array}$ & $\begin{array}{c}0.009 \\
\pm 0.002\end{array}$ & $\begin{array}{c}\mathbf{0 . 0 3 0} \\
\pm \mathbf{0 . 0 0 7}\end{array}$ & & & & $\begin{array}{c}0.008 \\
\pm 0.002\end{array}$ & $\begin{array}{c}0.035 \\
\pm 0.015\end{array}$ & \\
\hline
\end{tabular}

IM, intramuscular; IV, intravenous

${ }^{\mathrm{a}}$ Time from injection of first bolus to injection of top-up

${ }^{\mathrm{b}}$ Time from injection of first bolus to injection of reversal drugs

${ }^{\mathrm{c}}$ This bull (number 2) was given a reversing agent after 90 min following collapse onto his carpal joints 
A combination of medetomidine $(20 \mathrm{mg} / \mathrm{mL}$, Kyron Laboratories) and butorphanol (50 mg/mL, Kyron Laboratories) were drawn up into one syringe. Males were either guided into a restraint chute or pen system, where they were injected IM by hand, or were darted while free-standing outside and only restrained thereafter.

When the tip of the elephant's trunk was fully relaxed and resting on the ground, attempts to access the animal began. If, after $30 \mathrm{~min}$, the elephant was still responsive to handling of the tail, or the trunk was not permanently resting on the ground, or leg movements were present, an IV or IM top-up was given (Table 2). During the last round of sedations (n=8) 1000 to 2000 IU hyaluronidase (Hylase, 5000 IU per vial, Kyron Laboratories) were added to the cocktail to promote rapid drug resorption. For reversal of the sedations, naltrexone (Trexonil, $50 \mathrm{mg} / \mathrm{mL}$, Wildlife Pharmaceuticals) and atipamezole (Antisedan, 5 $\mathrm{mg} / \mathrm{mL}$, Zoetis) were administered IM or partially IV in separate syringes.

Table 2 shows the drugs and dosages used to sedate and reverse each of the 12 bulls treated 1-4 times. The mean intervals from injection until the first observed effect were 7.7 $\min (5-12 \mathrm{~min})$ without hyaluronidase and $12 \mathrm{~min}$ (5-30 $\mathrm{min})$ after the addition of hyaluronidase. Average time to full sedation was $25.5 \mathrm{~min}(10-52 \mathrm{~min})$ without hyaluronidase. The addition of hyaluronidase significantly reduced the time to full sedation to $16.5 \mathrm{~min}$ (12-33 min). The statistical analysis was performed using GraphPad InStat Version 3 software for a paired $t$ test $(P=0.024 ; \mathrm{df}=7 ; n=8$ bulls $)$.

For 11 sedations in seven bulls, a top-up dose was needed 25-30 min after administration of the initial bolus (Table 2). Mean total duration of sedation required for all 
procedures to be completed was $75 \pm 20 \mathrm{~min}(48-110 \mathrm{~min})$. In a single case, the youngest elephant (number 2) partially collapsed onto his carpal joints about 85 min after administration of the sedative drugs (Table 2). The drug was immediately reversed with 25 mg atipamezole and $50 \mathrm{mg}$ naltrexone IV and an additional $100 \mathrm{mg}$ naltrexone IM. He regained his footing rapidly and was fully conscious after 3 min.

All sedations were partially or completely reversed with IM atipamezole and naltrexone (Table 2). On seven occasions, one-third of the dose was given IV and the remainder given IM. In both cases, full recovery was achieved quickly and took on average 7 $\pm \mathrm{SD} 4 \mathrm{~min}(2.5-18.0 \mathrm{~min})$.

The results show that the combination of medetomidine $(0.009 \pm \mathrm{SD} 0.002 \mathrm{mg} / \mathrm{kg})$ and butorphanol $(0.03 \pm \mathrm{SD} 0.007 \mathrm{mg} / \mathrm{kg})$ provided a safe and reliable method for standing sedation of African elephant bulls after an induction period of 20 - 30 min. A supplemental injection of $0.003 \pm \mathrm{SD} 0.001 \mathrm{mg} / \mathrm{kg}$ medetomidine and $0.007 \pm \mathrm{SD} 0.003 \mathrm{mg} / \mathrm{kg}$ butorphanol was required for each of the 11 procedures. Induction times were significantly reduced when 1000-2000 IU hyaluronidase were added to the drug combination. This enzyme is used to facilitate drug resorption during wildlife immobilizations (Morton and Kock, 1991).

Medetomidine is the most potent of the $\alpha_{2}$-adrenoreceptor agonist family with more specific actions on receptors associated with sedation and analgesia (Fowler and Mikota, 2006). Previously, however, only detomidine in combination with butorphanol in a 1:1 ratio has been described for African elephants (Neiffer et al., 2005; Table 1).

The mean dose of medetomidine administered in combination with butorphanol in this study was almost twice the dose used for captive Asian elephants (Sarma et al., 2002) in 
which acceptable standing sedation was achieved using medetomidine alone. Asian elephants appear to be far more sensitive to the $\alpha_{2}$-agonists. For example, the recommended dose for detomidine in Asian elephants is $0.0055 \mathrm{mg} / \mathrm{kg}$ (Fowler and Mikota, 2006), whereas African elephants require 0.013-0.02 mg/kg (Neiffer et al., 2005; Table 1).

All of our elephants were able to walk out of the restraint pen or chute within 10-15 min after administration of the antidotes. The reversibility of both drugs used in the present study is a great advantage over drug combinations that include ketamine or azaperone, which have no reversal agent. Adverse gastrointestinal side effects (such as bloat or mild colic), as have been described after similar sedations in African elephants (Neiffer et al., 2005), were not seen. The only side effect we observed was increased salivation in all bulls.

In conclusion, this study determined an effective and fully reversible combination dose of medetomidine and butorphanol required to achieve standing sedation in African elephant bulls. The inclusion of hyaluronidase in the sedative cocktail significantly reduced the induction time.

\section{Conflict of interest statement}

None of the authors of this paper has a financial or personal relationship with other people or organisation that could inappropriately influence or bias the content of the paper.

\section{Acknowledgments}

The authors would like to thank the US Fish and Wildlife Service for funding this study (African elephant fund AFE 0705) as well as the International Elephant Foundation (Birmingham Zoo, USA) and Technology Innovation Agency (Pretoria, South Africa) for 
additional funding. The German Academic Exchange Service (DAAD) financially supported

IL in South Africa. The authors also thank Drs. D. Grobler and P. Rogers who were

responsible for carrying out some of the sedations.

\section{References}

Fowler, M.E., Mikota, S.K. 2006. Chemical restraint and general anesthesia, Section I: Chemical restraint. In Biology, Medicine, and Surgery of Elephants. Eds M.E. Fowler and S.K. Mikota Blackwell Publishing, pp. 91-110.

Hanks, J. 1972. Reproduction of elephant, Loxodonta africana, in the Luangwa Valley, Zambia. Journal of Reproduction and Fertility 30, 13-26.

Johnson, O.W., Buss, I.O. 1965. Molariform teeth of male African elephants in relation to age, body dimensions and growth. Journal of Mammalogy 46, 373-384.

Laws, R.M., Parker, I.S.C., Johnstone, R.C.B. 1975. Elephants and their habitats. Clarendon Press, Oxford.

Morton, D.J., Kock, M.D. 1991. Stability of hyaluronidase in solution with etorphine and xylazine. Journal of Zoo and Wildlife Medicine 22, 345-347.

Neiffer, D.L., Miller, M.A., Weber, M., Stetter, M., Fonteno, D.K., Robbins, P.K., Pye, G.W. 2005. Standing sedation in African elephants (Loxodonta africana) using detomidinebutorphanol combinations. Journal of Zoo and Wildlife Medicine 36, 250-256.

Sarma, B., Pathak, S.C., Sarma, K.K. 2002. Medetomidine - a novel immobilizing agent for the elephant (Elephas maximus). Research in Veterinary Science 73, 315-317. 